\title{
BMJ Open Young people's use of NHS Direct: a national study of symptoms and outcome of calls for children aged 0-15
}

\author{
E J Cook, ${ }^{1}$ G Randhawa,${ }^{2}$ S Large,${ }^{3}$ A Guppy, ${ }^{1}$ A M Chater, ${ }^{4}$ D Pang ${ }^{2}$
}

To cite: Cook EJ,

Randhawa G, Large S, et al. Young people's use of NHS Direct: a national study of symptoms and outcome of calls for children aged $0-15$. BMJ Open 2013;3:e004106. doi:10.1136/bmjopen-2013004106

- Prepublication history for this paper is available online. To view these files please visit the journal online (http://dx.doi.org/10.1136/ bmjopen-2013-004106).

Received 23 September 2013 Revised 31 October 2013 Accepted 5 November 2013

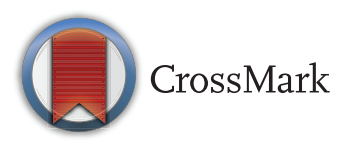

${ }^{1}$ Department of Psychology, University of Bedfordshire, Luton, Bedfordshire, UK

${ }^{2}$ Institute for Health Research, University of Bedfordshire, Luton, Bedfordshire, UK

${ }^{3}$ Research and Clinical Audit, NHS Direct, Hedge End, Hampshire, UK

${ }^{4}$ Centre for Behavioural Medicine, University College London, London, UK

Correspondence to Dr Erica Jane Cook; erica.cook@beds.ac.uk

\section{ABSTRACT}

Objectives: National Health Service (NHS) Direct provides 24/7 expert telephone-based healthcare information and advice to the public in England. However, limited research has explored the reasons to why calls are made on behalf of young people, as such this study aimed to examine call rate (CR) patterns in younger people to enable a better understanding of the needs of this population in England.

Setting: NHS Direct, England, UK.

Participants and methods: CRs (expressed as calls/ 100 persons/annum) were calculated for all calls ( $\mathrm{N}=358503$ ) made to NHS Direct by, or on behalf of, children aged $0-15$ during the combined four '1-month' periods within a year (July 2010, October 2010, January 2011 and April 2011). $\chi^{2}$ Analysis was used to determine the differences between symptom, outcome and date/time of call.

Results: For infants aged $<1$, highest CRs were found for 'crying' for male ( $n=14,440, C R=13.61)$ and female $(n=13654, C R=13.46)$ babies, which is used as a universal assessment applied to all babies. High CRs were also found for symptoms relating to 'skin/hair/ nails' and 'colds/flu/sickness' for all age groups, whereby NHS Direct was able to support patients to self-manage and provide health information for these symptoms for $59.7 \%$ and $51.4 \%$ of all cases, respectively. Variations in CRs were found for time and age, with highest peaks found for children aged 4-15 in the 15:00-23:00 period and in children aged $<1$ in the 7:00-15:00 period.

Conclusions: This is the first study to examine the symptoms and outcome of calls made to NHS Direct for and on behalf of young children. The findings revealed how NHS Direct has supported a range of symptoms through the provision of health information and self-care support which provides important information about service planning and support for similar telephone-based services.

\section{BACKGROUND}

National Health Service (NHS) Direct introduced in $1997^{1}$ provides 24/7 expert telephone-based healthcare advice and information which has aimed to support the public to care for themselves at home or

\section{Strengths and limitations of this study}

- This is the first study to examine the symptoms and outcome of calls made to NHS Direct for and on behalf of young children (0-15).

- National call data across four 1-month periods (July 2010, October 2010, January 2011 and April 2011) were linked to population statistics to determine symptom variations by the rates of calls/100 person/annum.

- While patient data provide important information about the patient, they do not take into account the characteristics of the caller.

- While this study uncovers the analysis of over 342000 paediatric patients, there was a large sample of calls removed from the analysis $(\mathrm{N}=100390)$ for symptom classifications, as these were dealt with by the front-end health advisor.

access appropriate healthcare. However, following the recent white paper 'Equity and Excellence: Liberating the NHS' and Lord Darzi's report 'High Quality Care for All', the way the public access healthcare information, advice and services on the telephone is set to change, with NHS Direct's telephone service (08 454647 ) being replaced by NHS 111 in England. ${ }^{2}{ }^{3}$ The new '111' service similar to NHS Direct provides 24/7 telephone-based health; however, marked differences focus on it being a free-to-call service, acting as a first port of call for all urgent but not emergency calls in an attempt to make it easier for the public to access local health services in and out of hours. ${ }^{4}$

Children continue to represent one of the highest users of healthcare, for general practitioner (GP) consultations ${ }^{5}{ }^{6}$ and hospital admissions $^{7}$ with research suggesting that two-thirds of hospital admissions (68\%, 500935 of 738805 ) were for children aged under five. This trend has steadily increased over the past 10 years with increased admissions of children aged $<1$ and $1-4$ by $52 \%$ 
and $25 \%$, respectively. ${ }^{8}$ However, NHS Direct has become a good way to support this population through its increased popularity with research highlighting that the highest users of this service are on behalf of children under five contributing to nearly $25 \%$ of all calls. ${ }^{9-12}$

However, while children are the highest users of NHS Direct, there has been limited research that has explored how this subgroup has engaged with this service. With the opportunity of using NHS Direct call data, ${ }^{13}$ the present study aims to examine call rate (CR) differences in symptoms of younger people $(0-15)$ who have used this service, additionally exploring the impact of age and gender on uptake. Moreover, this study aims to investigate the outcome of how these symptoms are managed in this subgroup which will provide useful information to current policy-makers to know how the NHS better manages demand for healthcare following the on-going interest to manage non-urgent emergency admission. ${ }^{7}$

\section{METHODOLOGY}

Dataset and participants

NHS Direct calls $(\mathrm{N}=358503)$ were extracted from the computerised assessment system (CAS) which is used to enable the nurse and health advisor to support and record consultations with patients. The sample in this research is all calls about children aged $0-15$ who used NHS Direct for a symptomatic consultation using the core health and information telephone advice line (08 454 647) in England over a 1-year period, during the combined month periods of July 2010, October 2010, January 2011 and April 2011.

\section{Variables}

Date and time of day

The data included the date and time of day of the call and were recoded into three categories: day (7:00-15:00), evening (15:00-23:00) and night (23:007:00). Calls were also calculated to identify whether they were a normal working day or a weekend/bank holiday.

\section{Age}

The threshold of age taken followed previous research that has focused on young cohorts. ${ }^{14}$ Children's ages were divided into three groups $(<1,1-3$ and $4-15$ years $)$ to take into account school age as well as to explore symptomatic differences between the large number of calls on behalf of young children (0-3) which together represent $66.2 \%$ of all childhood calls.

\section{Gender}

The gender of the patient of the calls was taken to look at gender differences in relation to symptom and outcome. Gender was analysed for 342641 patients, with 15862 missing cases excluded where gender was not reported. There were $50.8 \%(\mathrm{~N}=173982)$ of calls for or on behalf of male patients with the remaining $49.2 \%$ $(\mathrm{N}=168659)$ for or on behalf of female patients.

\section{Symptom classification}

The symptoms logged were categorised into 14 groups (see table 3) according to the classification and definition of medical subject headings $(\mathrm{MeSH})^{15}$ and have been previously applied to NHS Direct data. ${ }^{16}$ However, there was one additional group added which included 'colds and flu' because of the large volume of calls with symptoms that were specific to this category. Symptom classifications logged were analysed for 258113 patients, whereby there were 100390 missing cases which were excluded from analysis. Missing data reflect that are closed by the front-end advisor as they are related to simple quick-health information-related calls that do not warrant a symptom classification or to be discussed with a nurse advisor.

\section{Outcome of calls}

Following the assessment by nurses (supported using the CAS), patients are given an outcome following their call. The outcome of calls was categorised into 11 groups: self-care, GP urgent, GP same day, GP routine, health/ medication information, accident and emergency service (A\&E), 999, community, walk in centre, dental and other (see table 1).

\section{STATISTICAL METHODS}

Descriptive statistics were used to examine the use of NHS Direct. To facilitate data analysis and reporting, variables were categorised into appropriate groups. Rates of calls/100 persons/annum were calculated to measure the call usage using population estimates based

\begin{tabular}{|c|c|}
\hline \multicolumn{2}{|l|}{ Outcome } \\
\hline Self-care & $\begin{array}{l}\text { Advice given on how to look after the } \\
\text { problem }\end{array}$ \\
\hline GP urgent & Seek urgent appointment with GP \\
\hline GP same day & $\begin{array}{l}\text { Seek appointment with GP on the same } \\
\text { day }\end{array}$ \\
\hline GP routine & $\begin{array}{l}\text { Seek next available appointment with } \\
\text { GP }\end{array}$ \\
\hline $\begin{array}{l}\text { Health/ } \\
\text { medication } \\
\text { Information }\end{array}$ & $\begin{array}{l}\text { Either information given over telephone } \\
\text { or leaflets posted }\end{array}$ \\
\hline$A \& E$ & $\begin{array}{l}\text { Advised to attend accident and } \\
\text { emergency appointment }\end{array}$ \\
\hline 999 & Call directed to 999 \\
\hline Community & $\begin{array}{l}\text { Referred to community service (includes } \\
\text { pharmacy, mental health services, social } \\
\text { services and community nursing) }\end{array}$ \\
\hline Dental & Referred to a dental service \\
\hline Walk-in-centre & Advised to attend a local walk-in-centre \\
\hline Other & $\begin{array}{l}\text { Aborted calls, no action required and } \\
\text { also where the agency referred to is not } \\
\text { specified }\end{array}$ \\
\hline
\end{tabular}


on the 2006 single-age population statistics which were revised using 2011 census data. ${ }^{17} \chi^{2}$ Test with adjusted standardised residuals (ASRs) was carried out to compare between-group differences for outcome alongside date and time of day.

Cross-tabulations $\left(\chi^{2}\right.$ tests) were used to test outcome differences by symptom classification. Missing responses were excluded on an analysis-by-analysis basis (ie, total responses included will vary across analyses). With a large number of cell sizes for some of the cross-tabulations, it can be difficult to determine which groups have significant differences within the analyses; therefore, ASRs were calculated for each of the cells in order to determine which cell differences contribute to the $\chi^{2}$ test results. All statistical analyses were carried out using SPSS.

\section{RESULTS}

\section{Age, gender and symptoms}

For male patients, CR for the population of children was analysed according to the symptom classification and age groupings (table 2). For children aged $<1$, the highest $\mathrm{CR}$ was for 'crying' for male ( $\mathrm{n}=14440, \mathrm{CR}=13.61)$ and female ( $\mathrm{n}=13$ 654, $\mathrm{CR}=13.46$ ) children, alongside 'digestive problems' for male $(\mathrm{n}=3976, \mathrm{CR}=3.75)$ and female $(\mathrm{n}=3637, \mathrm{CR}=3.58)$ children, and 'skin/hair/nails' for male $(n=3887, C R=3.66)$ and female $(n=3864, C R=3.81)$ children. This was also supported for 'colds/flu/sickness' for male $(n=3765, C R=3.55)$ and female $(n=3861$, $\mathrm{CR}=3.63$ ) children, all demonstrating a higher CR. However, CR for 'body temperature' ( $\mathrm{n}=3238, \mathrm{CR}=3.04$ ) was substantially higher for male patients than for female patients ( $\mathrm{n}=6323, \mathrm{CR}=2.19$ ) .

CR decreased with increasing age. For ages 1-3, CR was highest (excluding other) for 'skin/hair/nails' for male $(\mathrm{n}=6853, \mathrm{CR}=2.26)$ and female $(\mathrm{n}=6531, \mathrm{CR}=2.26)$ children, alongside body temperature change for male $(\mathrm{n}=6378, \mathrm{CR}=2.10)$ and female $(6323, \mathrm{CR}=2.19)$ children. Lowest CRs for both genders were 'neurological disorders', 'crying' and 'lumps'. For ages 4-15, CR continued to decrease; however, highest CRs aside from 'other' were found for 'pain' for male $(\mathrm{n}=5415, \mathrm{CR}=0.43)$ and female $(\mathrm{n}=5371, \mathrm{CR}=0.44)$ children, 'wounds and injuries' for male $(\mathrm{n}=4472, \mathrm{CR}=0.35)$ and female $(\mathrm{n}=4238, \mathrm{CR}=0.35)$ children and 'skin/hair/nails' for male $(n=4025$, $\mathrm{CR}=0.32)$ and female $(\mathrm{n}=3906, \mathrm{CR}=0.32)$ children.

\section{Symptom and outcome}

Figure 1 presents all outcomes for all three age groups. The highest percentage of calls across all age groups were given health information and/or self-care advice, suggesting that a combined $47 \%$ of all calls made on behalf of children aged $<1,48.7 \%$ of calls on behalf of children $1-3$ and $43.9 \%$ of all calls made by or on behalf of children aged 4-15 were managed with no onward referral needed. For children aged $<1$, only $7 \%$ of calls were forwarded to A\&E, which was markedly higher for children aged 1-3 (12.3\%) and for children aged 4-15
(13.5\%). However, for GP outcomes (urgent/same day/ routine), this was higher for children aged $<1 \quad(30 \%)$ than for children aged 1-3 (24.5\%) and 4-15 (23.5\%).

For each symptom, cross-tabulation was completed to determine the ASRs between groups for outcome (table 3). 'Dental' and 'mental health' were excluded due to the small number of cases. $\chi^{2}$ Analysis confirmed that there was a significant interaction between symptom $\times$ outcome for male $\left(\chi^{2}=7141.77, \mathrm{df}=1,20 ; \mathrm{p}<0.001\right)$ and female $\left(\chi^{2}=633157, \mathrm{df}=1,20 ; \mathrm{p}<0.001\right)$ children. However, as there was little variation, this was reported for both genders combined for all ages $\left(\chi^{2}=1320913, \mathrm{df}=1,20 ; \mathrm{p}<0.001\right)$.

The symptoms which contributed to the highest number for urgency was 'respiratory tract' $(\mathrm{n}=840,5.1 \%$, $\mathrm{ASR}=32.7)$ and 'neurological disorders' ( $\mathrm{n}=51,8.4 \%$, ASR=12.1) with the highest number of outcomes being 999. There were a range of symptoms which required the highest number for GP referral outcome. These symptoms included 'crying' ( $\mathrm{n}=5473,16.5 \%, \mathrm{ASR}=84.8)$ and 'pain', where the highest outcome was GP urgent $(\mathrm{n}=1536,12 \%$, ASR $=28.9)$. Both 'sensation disorders' $(\mathrm{n}=1339,23.4 \%, \mathrm{ASR}=26)$ and 'lumps' $(\mathrm{n}=424,33.6 \%$, $\mathrm{ASR}=23.2)$ showed GP routine as the highest outcome. Finally, 'urogenital disorders' $(\mathrm{n}=935,31.3 \%$, ASR $=25.6)$, 'body temperature change' $(\mathrm{n}=4913,23 \%, \mathrm{ASR}=35.3)$ and 'digestive problems' $(\mathrm{n}=2938,19.3 \%, \mathrm{ASR}=16)$ all had the highest outcome of GP same day.

NHS Direct supported a wide range of callers to selfmanage their symptoms; the health information was the highest recorded outcome for these calls. These symptoms included 'poisoning and overdose' (low-risk unintentional overdose with low-toxic substance), where the highest number for outcome was self-care $(n=5458$, $56.6 \%, \mathrm{ASR}=42.4 \%)$ and health information $(\mathrm{n}=1930$, $20 \%$, ASR=23.4). This was similar for 'skin/hair/nail', where the highest number for outcome was also self-care $(\mathrm{n}=12526,43.2 \%, \mathrm{ASR}=25.9)$ and health information $(\mathrm{n}=4859, \quad 16.7 \%, \quad \mathrm{ASR}=24.3)$. 'Medicine enquiries' showed that the highest number for outcome was selfcare $(\mathrm{n}=1852,62.6 \%, \quad \mathrm{ASR}=29.9)$ as did 'wounds and injuries' ( $\mathrm{n}=7928,38.7 \%, \mathrm{ASR}=7.5)$. For 'colds and flu/sickness', the number for outcome of the outcome was for health information $(n=4156,16.9 \%$, ASR=22.7).

\section{Time and date of call}

There was a significant interaction between age and date of call, that is, whether the call was on a bank holiday or on a weekend compared with a normal working day $\left(\chi^{2}=14.83, \mathrm{df}=2,1 ; \mathrm{p}<0.001\right)$. From the total number of calls $(\mathrm{N}=342641), 59.7 \%(\mathrm{~N}=20671)$ were made on a weekday with the remaining $40.3 \%(\mathrm{~N}=137970)$ of calls made on a weekend or bank holiday during GP closure days, this finding remains consistent across the three age groups. To identify which cell differences contribute to the $\chi^{2}$ test results, ASRs were calculated for each of the cells. It was found that for calls taken during weekdays represented the highest number of calls made on behalf of children aged $<1 \quad(n=55271,27 \%, A S R=2.8)$; however, 
Table 2 Volume and rate of calls/100 population/annum (CR) according to age group and symptom classification group

\begin{tabular}{|c|c|c|c|c|c|c|c|c|c|c|c|c|c|c|c|c|}
\hline \multirow[b]{3}{*}{ Symptom classification group } & \multicolumn{8}{|l|}{ Males } & \multicolumn{8}{|c|}{ Females } \\
\hline & \multicolumn{2}{|l|}{$<1$} & \multicolumn{2}{|l|}{$1-3$} & \multicolumn{2}{|l|}{ 4-15 } & \multicolumn{2}{|l|}{ Total } & \multicolumn{2}{|c|}{$<1$} & \multicolumn{2}{|l|}{$1-3$} & \multicolumn{2}{|l|}{ 4-15 } & \multicolumn{2}{|l|}{ Total } \\
\hline & $\mathbf{N}$ & CR & $\mathbf{N}$ & CR & $\mathbf{N}$ & CR & $\mathbf{N}$ & CR & $\mathbf{N}$ & CR & $\mathbf{N}$ & CR & $\mathbf{N}$ & CR & $\mathbf{N}$ & CR \\
\hline Pain & 220 & 0.21 & 1034 & 0.34 & 5415 & 0.43 & 6669 & 0.40 & 180 & 0.18 & 777 & 0.27 & 5371 & 0.44 & 6328 & 0.40 \\
\hline Digestive problems & 3976 & 3.75 & 2624 & 0.86 & 1352 & 0.11 & 7952 & 0.48 & 3637 & 3.58 & 2574 & 0.89 & 1195 & 0.10 & 7406 & 0.46 \\
\hline Respiratory tract & 2908 & 2.74 & 3501 & 1.15 & 2152 & 0.17 & 8561 & 0.51 & 2592 & 2.55 & 3143 & 1.09 & 2043 & 0.17 & 7778 & 0.49 \\
\hline Wounds and injuries & 1996 & 1.88 & 4253 & 1.40 & 4472 & 0.35 & 10721 & 0.64 & 1894 & 1.87 & 3835 & 1.33 & 4238 & 0.35 & 9967 & 0.62 \\
\hline Sensation disorders & 478 & 0.45 & 1147 & 0.38 & 1233 & 0.10 & 2858 & 0.17 & 481 & 0.47 & 1123 & 0.39 & 1290 & 0.11 & 2894 & 0.18 \\
\hline Urogenital disorders & 165 & 0.16 & 430 & 0.14 & 722 & 0.06 & 1317 & 0.08 & 58 & 0.06 & 627 & 0.22 & 995 & 0.08 & 1680 & 0.11 \\
\hline Medicine enquiries & 401 & 0.38 & 446 & 0.15 & 634 & 0.05 & 14881 & 0.09 & 360 & 0.35 & 433 & 0.15 & 691 & 0.06 & 1484 & 0.09 \\
\hline Dental problems & 129 & 0.12 & 692 & 0.23 & 3098 & 0.25 & 3919 & 0.23 & 94 & 0.09 & 617 & 0.21 & 2892 & 0.24 & 3603 & 0.23 \\
\hline Poisoning and overdose & 686 & 0.65 & 2960 & 0.98 & 1245 & 0.10 & 4891 & 0.29 & 678 & 0.67 & 2883 & 1.00 & 1182 & 0.10 & 4743 & 0.30 \\
\hline Skin/hair/nail & 3887 & 3.66 & 6853 & 2.26 & 4026 & 0.32 & 14766 & 0.88 & 3864 & 3.81 & 6531 & 2.26 & 3906 & 0.32 & 14301 & 0.90 \\
\hline Body temperature change & 3238 & 3.04 & 6378 & 2.10 & 1276 & 0.10 & 10882 & 0.65 & 2923 & 2.88 & 6323 & 2.19 & 1243 & 0.10 & 10489 & 0.66 \\
\hline Lumps & 170 & 0.16 & 221 & 0.07 & 238 & 0.02 & 629 & 0.04 & 178 & 0.18 & 231 & 0.08 & 228 & 0.02 & 637 & 0.04 \\
\hline Neurological disorders & 40 & 0.04 & 98 & 0.03 & 150 & 0.01 & 288 & 0.02 & 35 & 0.03 & 86 & 0.03 & 200 & 0.02 & 321 & 0.02 \\
\hline Colds/flu/sickness & 3765 & 3.55 & 5045 & 1.66 & 3622 & 0.29 & 12432 & 0.74 & 3861 & 3.63 & 4972 & 1.72 & 3614 & 0.30 & 12267 & 0.77 \\
\hline Crying & 14440 & 13.61 & 2524 & 0.83 & 166 & 0.01 & 17130 & 1.02 & 13654 & 13.46 & 2346 & 0.81 & 158 & 0.01 & 16163 & 1.01 \\
\hline Other & 747 & 0.70 & 13448 & 4.43 & 12785 & 1.01 & 26980 & 1.61 & 740 & 0.73 & 12653 & 4.38 & 13139 & 1.09 & 26057 & 1.63 \\
\hline Total & 37236 & 35.09 & 51654 & 17.01 & 42612 & 3.37 & 131502 & 7.86 & 35054 & 34.55 & 49154 & 17.00 & 42385 & 3.52 & 126593 & 7.94 \\
\hline
\end{tabular}


Table 3 Percentage and number of cases of outcome by symptom

\begin{tabular}{|c|c|c|c|c|c|c|c|c|c|c|c|c|c|c|c|c|c|c|c|c|c|c|c|c|}
\hline \multirow[b]{2}{*}{ Symptom } & \multicolumn{2}{|l|}{999} & \multicolumn{2}{|l|}{ A\&E } & \multicolumn{2}{|c|}{ Dental } & \multicolumn{2}{|c|}{$\begin{array}{l}\text { Health } \\
\text { information }\end{array}$} & \multicolumn{2}{|c|}{ Self-care } & \multicolumn{2}{|c|}{ Other } & \multicolumn{2}{|c|}{ GP routine } & \multicolumn{2}{|c|}{ GP same day } & \multicolumn{2}{|c|}{ GP urgent } & \multicolumn{2}{|c|}{ Community } & \multicolumn{2}{|c|}{ Walk-in-centre } & \multicolumn{2}{|l|}{ Total } \\
\hline & $\mathbf{N}$ & $\begin{array}{l}\text { Per } \\
\text { cent }\end{array}$ & $\mathbf{N}$ & $\begin{array}{l}\text { Per } \\
\text { cent }\end{array}$ & $\mathbf{N}$ & $\begin{array}{l}\text { Per } \\
\text { cent }\end{array}$ & $\mathbf{N}$ & $\begin{array}{l}\text { Per } \\
\text { cent }\end{array}$ & $\mathbf{N}$ & $\begin{array}{l}\text { Per } \\
\text { cent }\end{array}$ & $\mathbf{N}$ & $\begin{array}{l}\text { Per } \\
\text { cent }\end{array}$ & $\mathbf{N}$ & $\begin{array}{l}\text { Per } \\
\text { cent }\end{array}$ & $\mathbf{N}$ & $\begin{array}{l}\text { Per } \\
\text { cent }\end{array}$ & $\mathbf{N}$ & $\begin{array}{l}\text { Per } \\
\text { cent }\end{array}$ & $\mathrm{N}$ & $\begin{array}{l}\text { Per } \\
\text { cent }\end{array}$ & $\mathbf{N}$ & $\begin{array}{l}\text { Per } \\
\text { cent }\end{array}$ & $\mathbf{N}$ & $\begin{array}{l}\text { Per } \\
\text { cent }\end{array}$ \\
\hline Pain & 295 & 2.3 & 926 & 7.1 & 9 & 0.1 & 1257 & 9.7 & 3356 & 25.9 & 484 & 3.7 & 1901 & 14.6 & 2722 & 21.0 & 1563 & 12.0 & 160 & 1.2 & 305 & 2.4 & 12978 & 100 \\
\hline Digestive problems & 36 & 0.2 & 381 & 2.5 & 1 & 0.0 & 2419 & 15.8 & 4800 & 31.5 & 810 & 5.3 & 2539 & 16.6 & 2938 & 19.3 & 1081 & 7.1 & 106 & 0.7 & 151 & 1.0 & 15262 & 100 \\
\hline $\begin{array}{l}\text { Respiratory tract } \\
\text { problems }\end{array}$ & 840 & 5.1 & 1146 & 7.0 & 0 & 0.0 & 1961 & 12.0 & 4305 & 26.4 & 462 & 2.8 & 1961 & 12.0 & 3286 & 20.1 & 1903 & 11.7 & 199 & 1.2 & 260 & 1.6 & 16323 & 100 \\
\hline Wounds and injuries & 381 & 1.9 & 5477 & 26.7 & 39 & 0.2 & 2322 & 11.3 & 7928 & 38.7 & 787 & 3.8 & 1066 & 5.2 & 1053 & 5.1 & 246 & 1.2 & 308 & 1.5 & 881 & 4.3 & 20488 & 100 \\
\hline Sensation disorders & 17 & 3 & 208 & 3.6 & 6 & 0.1 & 709 & 12.4 & 1465 & 25.6 & 448 & 7.8 & 1339 & 23.4 & 912 & 15.9 & 128 & 2.2 & 217 & 3.8 & 282 & 4.9 & 5731 & 100 \\
\hline Urogenital disorders & 4 & 0.1 & 69 & 2.3 & 0 & 0.0 & 92 & 3.1 & 261 & 8.7 & 238 & 8.0 & 770 & 25.8 & 935 & 31.3 & 367 & 12.3 & 84 & 2.8 & 167 & 5.6 & 2987 & 100 \\
\hline Medicine enquiries & 0 & 0.0 & 10 & 0.3 & 11 & 0.4 & 629 & 21.3 & 1852 & 62.6 & 61 & 2.1 & 62 & 2.1 & 108 & 3.6 & 82 & 2.8 & 144 & 4.9 & 1 & 0.0 & 2960 & 100 \\
\hline $\begin{array}{l}\text { Poisoning and } \\
\text { overdose }\end{array}$ & 152 & 1.6 & 1694 & 17.6 & 2 & 0.0 & 1930 & 20.0 & 5458 & 56.6 & 189 & 2.0 & 53 & 0.6 & 88 & 0.9 & 46 & 0.5 & 11 & 0.1 & 12 & 0.1 & 9635 & 100 \\
\hline Skin/hair/nail & 376 & 1.3 & 1053 & 3.6 & 28 & 0.1 & 4859 & 16.7 & 12526 & 43.2 & 499 & 1.7 & 2610 & 9.0 & 4073 & 14.0 & 1010 & 3.5 & 1222 & 4.2 & 768 & 2.6 & 29024 & 100 \\
\hline $\begin{array}{l}\text { Body temperature } \\
\text { change }\end{array}$ & 553 & 2.6 & 1006 & 4.7 & 6 & 0.0 & 2667 & 12.5 & 6847 & 32.1 & 321 & 1.5 & 2756 & 12.9 & 4913 & 23.0 & 1848 & 8.7 & 138 & 0.6 & 306 & 1.4 & 21361 & 100 \\
\hline Lumps & 0 & 0.0 & 48 & 3.8 & 0 & 0.0 & 95 & 7.5 & 264 & 20.9 & 170 & 13.5 & 424 & 33.6 & 129 & 10.2 & 17 & 1.3 & 36 & 2.9 & 80 & 6.3 & 1263 & 100 \\
\hline $\begin{array}{l}\text { Neurological } \\
\text { disorders }\end{array}$ & 51 & 8.4 & 94 & 15.4 & 0 & 0.0 & 26 & 4.3 & 65 & 10.7 & 22 & 3.6 & 96 & 15.8 & 168 & 27.6 & 79 & 13.0 & 0 & 0.0 & 8 & 1.3 & 609 & 100 \\
\hline $\begin{array}{l}\text { Colds and flu/ } \\
\text { sickness }\end{array}$ & 223 & 0.9 & 1651 & 6.7 & 5 & 0.0 & 4156 & 16.9 & 8497 & 34.5 & 504 & 2.0 & 3335 & 13.5 & 4827 & 19.6 & 974 & 4.0 & 173 & 0.7 & 309 & 1.3 & 24654 & 100 \\
\hline $\begin{array}{l}\text { Crying } \\
\text { Total (N) }\end{array}$ & $\begin{array}{l}1159 \\
4087\end{array}$ & 3.5 & $\begin{array}{r}2810 \\
16573\end{array}$ & 8.5 & $\begin{array}{r}7 \\
114\end{array}$ & 0.0 & $\begin{array}{r}2164 \\
25286\end{array}$ & 6.5 & $\begin{array}{r}6671 \\
64295\end{array}$ & 20.2 & $\begin{array}{l}1344 \\
6339\end{array}$ & 4.1 & $\begin{array}{r}3722 \\
2344\end{array}$ & 11.2 & $\begin{array}{r}8489 \\
34641\end{array}$ & 25.7 & $\begin{array}{r}5473 \\
14817\end{array}$ & 16.5 & $\begin{array}{r}676 \\
3474\end{array}$ & 2.0 & $\begin{array}{r}578 \\
4108\end{array}$ & 1.7 & $\begin{array}{r}33093 \\
196368\end{array}$ & 100 \\
\hline
\end{tabular}




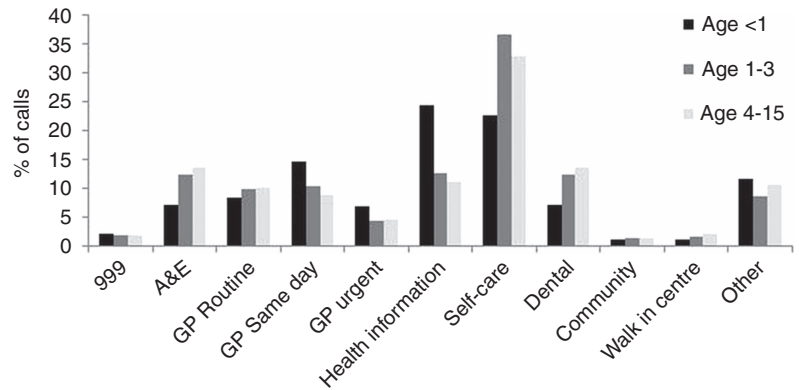

Figure 1 Outcome of triage for each age group $(<1,1-3$ and 4-15). A\&E, accident and emergency service; GP, general practitioner.

for calls during weekends and bank holidays, the largest number of calls was made on behalf of children $1-3$ years $(\mathrm{n}=52694,8.2 \%, \mathrm{ASR}=3.7)$.

$\chi^{2}$ Analysis highlighted a significant interaction by age $\times$ time of day $\left(\chi^{2}=13209.13, \mathrm{df}=20,1 ; \mathrm{p}<0.001\right)$. From the total number of calls $(\mathrm{n}=342641), 11.9 \%$ $(n=40817)$ of calls were made during 23:00-7:00, 36.1\% $(\mathrm{n}=123677)$ were made during 7:00-15:00 with the highest CR made within the hours 15:00-23:00 (52\%: $\mathrm{n}=178$ 147), with this finding remaining consistent across the three age groups (figure 2).

To identify which cell differences contribute to the $\chi^{2}$ test results, ASRs were calculated for each of the cells. The findings highlighted that there were clear age and time differences, whereby for the time period 23:00-7:00, the highest number of calls was made on behalf of children aged $1-3 \quad(n=15711,38.5 \%, A S R=3)$. However, for the time period 7:00-15:00, the highest number of calls was on behalf of children aged $<1$ $(\mathrm{n}=43352,27.8 \%, \mathrm{ASR}=9.4)$, with the highest number of calls made by or on behalf of children aged 4-15 for the time period 15:00-23:00 $(\mathrm{n}=64726,36.3 \%, \mathrm{ASR}=12.6)$.

\section{DISCUSSION}

Main findings of this study

There has been much controversy surrounding the extent that NHS Direct has managed to relieve the

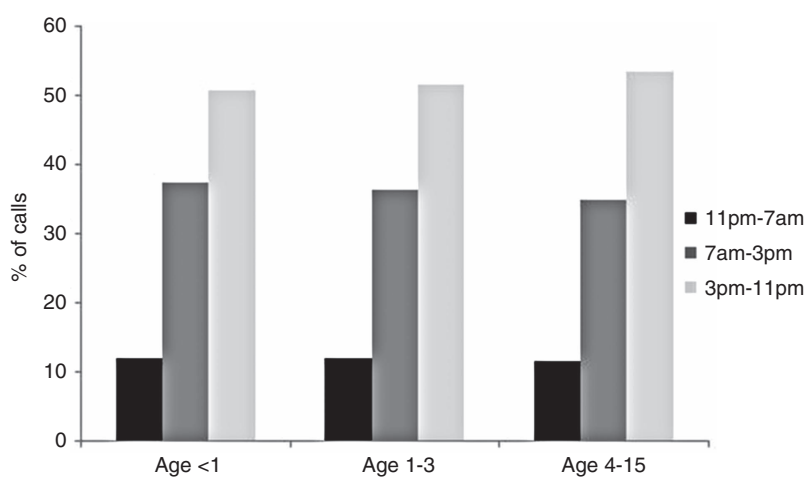

Figure 2 Distribution of calls by age groups across three time periods. pressure of overstretched healthcare services. ${ }^{8}$ However, NHS Direct survey data show that they are alleviating A\&E and GP services, with $41 \%$ of respondents being advised to treat themselves at home with $11 \%$ to A\&E and $28 \%$ to a GP, whereby it was reported that if these individuals did not phone, $44 \%$ would have gone to their GP with $29 \%$ to A\&E. ${ }^{18}$ Therefore, this research engages with this debate, providing a current understanding of how children use NHS Direct, in particular what symptoms they present and how these are managed.

Highest CRs to NHS Direct for children aged $<1$ were for 'crying', with this group using the service mostly between 7:00 and 15:00. It is important to note that NHS Direct advisors use the crying symptom classification for all children under 3 months old and is used as a catch-all algorithm for safety for children $<1$ which would have influenced this finding. However, this finding remains consistent with emergency admissions, with 'crying' contributing as a main symptom which new borns present at emergency departments nationally. ${ }^{19}$ While excessive crying has been viewed as a normal developmental phenomenon in babies, ${ }^{20}$ there is little agreement to the treatment or prevalence. ${ }^{21}$ Smith $^{22}$ suggests that parents of persistently crying babies need instant reassurance and support to cope, whereby health visitors have been viewed as best placed to offer this support. ${ }^{21}$ However, nurses at NHS Direct have also been well placed to use their clinical judgement in decision-making, instantly reassuring parents to help them cope ${ }^{22}$ where telephone-based health services may be best suited to provide mainly parents with more knowledge and information.

As supported by internal audits, the highest outcome of calls across all age groups was health information and/or self-care advice, with statistics suggesting around $40-50 \%$ of all calls made by or on behalf of children aged 0-15 were managed with no onward referral needed, which supports previous audits. ${ }^{18}$ CRs were particularly high for symptoms relating to 'skin/hair/nails' and 'colds/flu/sickness' for all age groups, whereby, NHS Direct was able to support patients to self-manage and provide health information to these symptoms for $59.7 \%$ and $51.4 \%$ of all cases, respectively. This suggests that NHS Direct is able to support more callers at home than previously reported, ${ }^{18}$ with only $7 \%$ of calls on behalf of children aged $<$ ladvised to attend A\&E and less children aged 1-3 and 4-15 advised to attend a GP.

The symptoms which contributed to the highest urgency were 'respiratory tract' and 'neurological disorder', with the highest outcomes being 999. Respiratory tract infections are the most frequent acute problems contributing around $25 \%$ of patients who consult within primary care ca $^{24}$ and around $40 \%$ of admissions to emergency services. ${ }^{8}$ However, NHS Direct has shown to safely support $38.4 \%$ of all children with this symptom through the provision of telephone-based self-care support and health information. Research has 
highlighted this to be an effective way of management, ${ }^{25-27}$ where medical information has proven successful in not only supporting children with respiratory tract infections, but ultimately also leading to important reductions in antibiotic prescribing and reduced intention to consult without reducing satisfaction with care. ${ }^{28}$

An interesting finding was that NHS Direct was able to successfully manage around $60 \%$ and $20 \%$ of calls relating to 'poisoning and overdose' characterised as low-risk unintentional overdose with low-toxic substances through the provision of self-care and health information, respectively. With ingestion of harmful substances being the most common causes of injury, and subsequently a common reason for referral to $\mathrm{A} \& \mathrm{E}$, this finding highlights that NHS Direct and essentially telephone-based healthcare can safely support parents and caregivers to appropriately and safely manage the child's symptoms within their own home. ${ }^{29}$

There were time differences noted, for example, calls on behalf of children aged 1-3 were highest throughout the night 23:00-7:00 However, for children aged $<1$, calls peaked during the hours of 7:00-15:00, this may suggest that NHS Direct is able to provide parents with instant reassurance of how to support a wide range of symptoms with the possibility of avoiding unnecessary GP visits. For children aged 4-15, CRs were found highest during the times of 15:00-23:00, where they had higher reporting of symptoms relating to 'wounds and injuries'. This may be a reflection of when school finishes, whereby NHS Direct was able to support $50 \%$ of all children through the provision of self-care support and health information. However, this finding could highlight a gap of knowledge to how parents of children can be best supported to look after children following school in relation to the provision of health information to help manage symptoms more effectively.

\section{LIMITATIONS}

This research focused on patient (child participant of the call) data rather than caller (usually the parent/ caregiver) data which does not provide useful information relating to the characteristics of the caller, whereby there is evidence that use of this service is dependent on the sociodemographic characteristics of the caller. $^{10}{ }^{30-32}$ Furthermore, while previous research has suggested that there is an upward trend of access associated with deprivation. ${ }^{30}$ However, this finding is not consistent across age, whereby deprivation is shown to be related to lower usage for or on behalf of children $(<15) .^{9} 12$ Therefore, it would be useful to explore the role of deprivation on the utilisation of this service in this cohort, which hopefully clarifies the point being made.

Although this study used a large sample of call data from 358503 child-patients, there were a number of cases managed and closed by front-end advisors, therefore $(\mathrm{N}=100390)$ which were removed from analysis for symptom classifications. Nonetheless, following prechecking, the remaining calls used within the analysis met the requirements of the research aim.

This study focused on four ' 1 -month' periods across a 1-year period; while it would have been more robust to have captured a full year sample, it was felt that the data would have been excessive, with the 4 months felt to still remain representative of the population uptake in England. There are no national studies to compare this with; however, previous studies that have used a 1-year sample have only had data on that population, for example, older people ${ }^{16}$ or have focused on a specific geographical area. ${ }^{12} 31$

Over the 4-month period, there could have been seasonality differences, which may have caused some bias towards some symptoms recorded, and it would have been interesting to have explored seasonality differences for this cohort. Nonetheless, while telephone-based healthcare systems such as NHS Direct have the potential for informing public health regarding the epidemiology of communicable diseases for common viruses such as influenza and norovirus ${ }^{33-36}$ in the community, this research provides an overview of how these symptoms are managed and the representativeness of these data.

\section{CONCLUSION}

This is the first study to examine the symptoms and outcome of calls made to NHS Direct for and on behalf of young children. It has highlighted that NHS Direct has supported a wide range of symptoms through the provision of health information and self-care support and provides important data relating to symptoms outcome and time of call. Moreover, it highlights the increasing role of telephone-based healthcare in England and how the use of technology can provide instant support and reassurance to parents through the provision of clinical knowledge and information to empower them to support many symptoms. As the new 111 telephone-based service is rolled out nationally, research should now focus on how this new service can further support the health of younger population groups and the impact this has on demand for other health services.

Contributors All authors contributed to the study conception/design. EJC, AG, GR and SL contributed to the data collection. EJC, AG, AMC, DP and SL conducted the data analysis, critically revised the article and reviewed the draft of the article.

Funding This research was jointly funded by NHS Direct and the University of Bedfordshire.

Competing interests None.

Ethics approval A favourable ethical opinion was obtained from the University of Bedfordshire and Essex 1 Research Ethics Committee (REF: 10/ H0301/29). Research governance approval was granted by NHS Direct prior to the start of the study.

Provenance and peer review Not commissioned; externally peer reviewed.

Data sharing statement No additional data are available. 
Open Access This is an Open Access article distributed in accordance with the Creative Commons Attribution Non Commercial (CC BY-NC 3.0) license, which permits others to distribute, remix, adapt, build upon this work noncommercially, and license their derivative works on different terms, provided the original work is properly cited and the use is non-commercial. See: http:// creativecommons.org/licenses/by-nc/3.0/

\section{REFERENCES}

1. Department of Health. A modern and dependable NHS. London: HMSO, 1997.

2. Department of Health. Equity and excellence: liberating the NHS. London: HMSO, 2010.

3. Department of Health. High quality care for all: NHS next stage review final report. Norwich: UK: The Stationery Office, 2008.

4. Department of Health. 111-The new number for the future of non-emergency health services. 2010 [cited 21 October 2011]. http://www.dh.gov.uk/en/MediaCentre/Pressreleases/DH_118861

5. Rosenstock IM. Why people use health services. Milbank $Q$ 2005;83:1-32.

6. Brogan C, Pickard D, Gray A, et al. The use of out of hours health services: a cross sectional survey. BMJ 1998;316:524-7.

7. Purdy S. Avoiding hospital admissions: what does the research say? London: The King's Fund, 2010.

8. Gill PJ, Goldacre MJ, Mant D, et al. Increase in emergency admissions to hospital for children aged under 15 in England, 1999-2010: national database analysis. Arch Dis Child 2013;98:328-34.

9. Cook EJ, Randhawa G, Large S, et al. Who uses telephone based helplines? Relating deprivation indices to users of NHS Direct. Health Policy Technol 2013;2:69-74.

10. Bibi M, Attwell RW, Fairhurst RJ, et al. Variation in the usage of NHS Direct by age, gender and deprivation level. J Environ Health Res 2005;4:63-8.

11. Payne F, Jessopp L. NHS Direct: review of activity data for the first year of operation at one site. J Public Health Med. 2001;23:155-8.

12. Cooper D, Arnold E, Smith G, et al. The effect of deprivation, age and sex on NHS Direct call rates. Br J Gen Pract 2005;55:287-91.

13. Cooper D, Chinemana F. NHS Direct derived data: an exciting new opportunity or an epidemiological headache? J Public Health 2004;26:158-60.

14. Stewart B, Fairhurst R, Markland J, et al. Review of calls to NHS Direct related to attendance in the paediatric emergency department. Emerg Med J 2006;23:911-14

15. United States National Library of Medicine. Medical Subject Headings (MeSH). 2008 [cited 22 May 2013]. http://www.nlm.nih. gov/mesh/

16. Hsu W, Bath PA, Large S, et al. Older people's use of NHS Direct. Age Ageing 2011;40:335-40.

17. Office for National Statistics. Mid-2006 population estimates: single year of age and sex for local authorities in England and Wales; estimated resident population revised in light of the 2011 census. Fareham, UK: Office for National Statistics, 2013.

18. NHS Direct. NHS Direct helps take the pressure off A\&E and GP's. NHS Direct Organisation, 2008.
19. Calado CS, Pereira AG, Santos VN, et al. What brings newborns to the emergency department? A 1-year study. Pediatr Emerg Care 2009;25:244-8.

20. Barr RG. What is all that crying about? Bull Centre Excellence Early Child Dev 2007;6:1-3.

21. Long $\mathrm{T}$, Johnson M. Living and coping with excessive infantile crying. J Adv Nurs 2001;34:155-62.

22. Smith S. Helping parents cope with crying babies: decision-making and interaction at NHS Direct. J Adv Nurs 2009;66:381-91.

23. Ashworth $\mathrm{M}$. Variations in antibiotic prescribing and consultation rates for acute respiratory infection in UK general practices 1995-2000. Br J Gen Pract 2005;55:603-8.

24. Ashworth M. Age-related changes in consultations and antibiotic prescribing for acute respiratory infections, 1995-2000. Data from the UK General Practice Research Database. J Clin Pharm Ther 2006;31:461-7.

25. NICE. Respiratory tract infections: prescribing of antibiotics for self-limiting respiratory tract infections in adults and children in primary care. 2008. [cited 26 May 2013]. http://guidance.nice.org.uk/

26. Arroll B, Kenealy T. Are antibiotics effective for acute purulent rhinitis? Systematic review and meta-analysis of placebo controlled randomised trials. BMJ 2006;333:279-82.

27. Altiner A, Brockmann S, Sielk M, et al. Reducing antibiotic prescriptions for acute cough by motivating GPs to change their attitudes to communication and empowering patients: a clusterrandomized intervention study. J Antimicrob Chemother 2007; 60:638-44.

28. Francis NA, Butler CC, Hood K, et al. Effect of using an interactive booklet about childhood respiratory tract infections in primary care consultations on reconsulting and antibiotic prescribing: a cluster randomised controlled trial. BMJ 2009;339:b2885.

29. Shannon M. Ingestion of toxic substances by children. N Engl J Med 2000;342:186-91.

30. Cook E, Randhawa G, Large S, et al. A UK case study of who uses NHS Direct? Investigating the impact of age, gender and deprivation on the utilisation of NHS Direct. Telemed J E Health 2012;18:693-8.

31. Bibi M, Attwell RW, Fairhurst RJ, et al. The usage of NHS Direct by different ethnic and gender groups in an urban population. Rev Environ Health 2008;23:235-41.

32. Hsu W-C, Bath PA, Large S, et al. The association of geographical location and neighbourhood deprivation with older people's use of NHS Direct: a population-based study. Age Ageing 2013:42:57-62.

33. Cooper DL, Verlander NQ, Smith GE, et al. Can syndromic surveillance data detect local outbreaks of communicable disease? A model using a historical cryptosporidiosis outbreak. Epidemiol Infect 2006;134:13-20.

34. Cooper D, Smith G, Regan M, et al. Tracking the spatial diffusion of influenza and norovirus using telehealth data: a spatiotemporal analysis of syndromic data. BMC Med 2008;6:16.

35. Cooper DL, Smith GE, Edmunds WJ, et al. The contribution of respiratory pathogens to the seasonality of NHS Direct calls. $J$ Infect 2007;55:240-8.

36. Loveridge P, Cooper D, Elliot AJ, et al. Vomiting calls to NHS Direct provide an early warning of norovirus outbreaks in hospitals. $J$ Hosp Infect. 2010;74:385-93. 